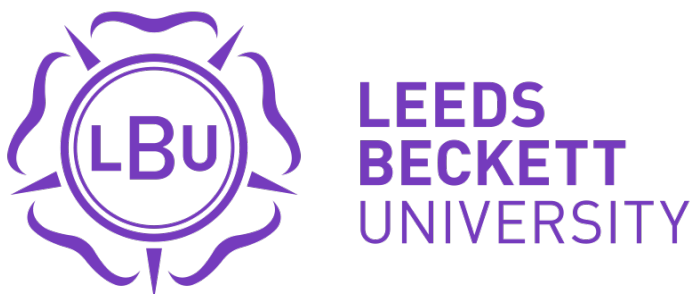

Citation:

Spracklen, K (2018) Opeth Not Metal: Making Sense of the Symbolic Boundary Work in the Leisure Spaces of Musicians and Fans. International Journal of the Sociology of Leisure. ISSN 2520-8683 DOI: https://doi.org/10.1007/s41978-018-00024-w

Link to Leeds Beckett Repository record:

https://eprints.leedsbeckett.ac.uk/id/eprint/5388/

Document Version:

Article (Accepted Version)

The aim of the Leeds Beckett Repository is to provide open access to our research, as required by funder policies and permitted by publishers and copyright law.

The Leeds Beckett repository holds a wide range of publications, each of which has been checked for copyright and the relevant embargo period has been applied by the Research Services team.

We operate on a standard take-down policy. If you are the author or publisher of an output and you would like it removed from the repository, please contact us and we will investigate on a case-by-case basis.

Each thesis in the repository has been cleared where necessary by the author for third party copyright. If you would like a thesis to be removed from the repository or believe there is an issue with copyright, please contact us on openaccess@leedsbeckett.ac.uk and we will investigate on a case-by-case basis. 


\section{Opeth Not Metal: Making Sense of the Symbolic Boundary Work in the Leisure Spaces of Musicians and Fans}

\section{Introduction}

Bradford Rio's, 2002 - Opeth are playing 'The Leper Affinity' from Blackwater Park. This is the best band ever. I am astounded by the virtuosity of the musicians. I am amazed by the growling of the lead singer. I have not been excited by heavy metal since the nineties and the rise of bands with baseball caps and breakbeats. This is pure extreme metal. I can't stop banging my head. Then what is this joyous moment? The music rises, the riffs turn into clean picking and the singer stops growling and sings. We are with him singing, then the growling and the riffs return, and they are even more intense.

Memories may be unreliable (though still defensible as sources as knowledge: Salvaggio 2018), but I still have a vivid re-collection of the night in the ethnographic reflection above. At the turn of the century, the Swedish heavy-metal band Opeth brought me back to heavy metal as a fan. What I loved about them was the contrast between the heavy moments and the more melodic, progressive elements. My own consumption of - and identification with - Opeth as a fan in my leisure time does not stop me being able to critically reflect on the nature of that fandom more generally, and the symbolic boundary work (Lamont 1992, 2000) at play in the heavy metal community as a leisure space (Hoad 2014; Hill 2016; Spracklen 2009, 2017; Spracklen, Lucas and Deeks 2014). Rather, my experience is at the heart of the symbolic boundary work around Opeth as the band have changed. In 2011, Opeth released the album Heritage. The album did not have any of the fast death-metal riffs the band had become known for, and nor did the album have any of the death-metal growl vocals. In fact, Opeth had already released an album of quiet and reflective songs - Damnation, in 2003. But that album was seen as a companion album to the very heavy album Deliverance, released in 2002. With the release of Heritage, the band's publicity and interviews with their frontman Mikael Åkerfeldt have made it abundantly clear that death-metal vocals and death-metal riffs are part of the band's history, and they are now courted and marketed as a serious, progressive rock band. Opeth have had a long, sustained and successful career in the heavy metal industry. In the early 1990s they signed to Candlelight Records in the UK, and released a trilogy of albums that drew on the death-doom heavy/clean passages of My Dying Bride (Yavuz 2017), as well as more conventional death metal and heavy metal of the eighties. As well as the metal influences, the band's early albums already demonstrated progressive rock influences, with long songs and complex musical arrangements the norm. By the time of the fourth studio album Still Life (1999) Opeth had moved across England to sign with Peaceville Records (Yavuz 2017). At Peaceville they were aligned with My Dying Bride, but also old-school death metal acts such as Autopsy. This album is perhaps the best Opeth album. It is the album fans score as the best (see below), and it is the one that encapsulated everything that became known as the Opeth sound and feel.

The band's early albums were well-received as important contributions to melodic death metal, but the band struggled to survive. Signing to small, independent extreme metal labels makes it difficult to sustain a career as a band and a musician; having critical acclaim does not pay the bills. However, Opeth found a key fan in this period: the prog musician Steven Wilson. A collaboration with Wilson as producer on the album Blackwater Park (2001) gave 
the band a hook-driven, complex and intelligent release that allowed them to build a higher profile in the metal scene. The album has furious riffs but also chilled-out, transcendental moments. ${ }^{1}$ It even has a reflective ballad with clean vocals, driven by acoustic guitars. Wilson remained as producer and amanuensis to lead singer and songwriter Mikael Åkerfeldt, and helped the band construct the next two albums, Deliverance and Damnation. The success of this collaboration led to the band signing to international label Roadrunner Records and becoming festival regulars. In 2005 they released Ghost Reveries, followed by Watershed in 2008. On these albums the band continued to explore melodic death-metal alongside progressive rock, and gained both critical acclaim and chart success: the latter album reaching 23 in the US Billboard ranking. ${ }^{2}$ In recent years, however, Mikael Akerfeldt has abandoned death-metal growls and metal riffs for songs that are inspired by his record collection seventies rock and prog - and released two albums that have abandoned the metal styling altogether.

Musicians have changed direction before under various motivations, from the ragtime bands (Berlin 2016) all the way to Bob Dylan plugging in his guitar (Cossu 2015), and fans have accused those musicians of 'selling out' (Cossu 2015; Hesmondhalgh 1998; Klein, Meier and Powers 2017; Nelson 2018). Or, if the musicians are not selling out, they are following a sound inspired by their creative muses, as parodied in the jazzed-up 'new direction' of Rob Reiner's classic spoof documentary This Is Spinal Tap (see discussion in Spirou 2014). Subgenres of rock such as extreme metal are particularly prone to having fans who are fearful about bands becoming what they argue is less authentic and more hybrid or mainstream (Hoad 2014; Kahn-Harris 2006; Spracklen 2006). ${ }^{3}$ Black metal, for example, is riven with arguments over definitions - who belongs to the underground, and why some bands cannot be black metal that stem from the communicative rationality at the heart of the sub-genre (Spracklen 2006, 2014). Opeth's career in extreme metal in the nineties and at the turn of the century reflected this commitment to the underground scene and its spaces. And even when they first hit the charts and headlined metal festivals, they played by the genre rules of melodic death metal (Phillipov 2012).

In the main sections of this paper, I will explore the band's justification of their evolution into a progressive rock band through on-line interviews and my own analysis, before showing how metal fans on-line have reacted strongly (and negatively) to this evolution. In the discussion and conclusion, I will analyse both the motivations of the band and the fans, which revolve around reactions to the hegemonic status of the cultural industries and leisure in modernity, and what Bauman (2000) identifies as the crisis of liquid modernity. Before this, it is necessary to discuss the theoretical framework in the paper, and the methods used to collect and analyse the data.

\section{Theoretical Framework}

My own previous work on leisure in late modernity, and music spaces, is underpinned by a number of ideas from key cultural and social theorists such as Gramsci, Adorno and Habermas

\footnotetext{
${ }^{1}$ It is my personal favourite, and was the release that took me to see the band play live for the first time in Bradford.

2 https://en.wikipedia.org/wiki/Watershed_(Opeth_album), accessed 19 June 2018.

${ }^{3}$ Fans in other leisure spaces have similar concerns about how the things they like might change and become something they can no longer identify with - whether that is a favourite football team taken over by a new, shady owner (Hewer, Gannon and Cordina 2017), or a science-fiction brand straying from its canon or values (Brown 2018).
} 
(Spracklen 2006, 2009, 2011, 2013a, 2015). In this paper, I am introducing the notion of liquid modernity (Bauman 2000) to my understanding of leisure spaces and identities. It is necessary to review the key ideas in my existing work before moving to Bauman (2000). Gramsci (1971) shows us how capitalists and elites maintain their power through hegemony. That is, they use the control of the media and culture to make the people without any power think they have power (Altheide 1994). Gramsci (1971) obviously wrote his critique of Italy at a time when the fascists had grabbed power by co-opting and manipulating the older systems and structures of the State. This was a bourgeois revolution against the landed elites of the old Establishment, one predicted in the work of Marx (cf, Marx and Engels 2002). But instead of rising up and attacking the people who denied them power, the working-classes remained content to be ruled by the fascists. This was because the Fascists used the media and culture to make people think they were content, offering people escape and the illusion of freedom. Sports and music became key leisure spaces encouraged by the State because they allowed working-class men in particular to feel as if they had the agency to choose between supporting one team or another. The working classes gambled, consumed newspapers and magazines with details and arguments about sports, and listened to the radio to music and sports commentaries believing all of it to be a good and free leisure choice of their own (Spracklen 2011).

Gramsci was writing about Italy, but his model of hegemony can be seen to be at work in all modern nation-states to a greater or lesser degree: but especially in these populist times of Brexit, Trump and the assorted ranks of dictators and demagogues that hold power through controlling the public sphere. The media and culture are always something constructed by elites and consumed by others, even if postmodernity and globalization challenge the dominance of those elites (Engesser, Ernst, Esser and Büchel 2017). Adorno and Horkheimer (2002) of the Frankfurt School were the first theorists to show how modernity has commodified culture. In that work and in other essays and books on the subject, Adorno (2005) argued persuasively for the emergence of the culture industry, an industry creating a factory-built form of popular or mass culture that stupefied those who consumed it. This culture industry was evident to Adorno in the film studios, jazz bands and radio stations of his day. This modern, mass-produced culture had little aesthetic value but appealed to baser instincts. Instead of the working-classes using culture and leisure to better their education and their humanity, instead of using culture and leisure as spaces of resistance, the masses were tricked into consuming and forgetting the nature of their oppression. In recent years there has been a dismissal of Adorno's rejection of popular music as a form of elite snobbery (Frith 1998; Paddison 1982). There is indeed obviously some value in some forms of popular music (Frith 1998; Hesmondhalgh 2013), and I have argued for the importance of heavy metal, for example, in a number of places (Spracklen 2006, 2014). But it cannot be denied that all forms of music today - even folk and classical, and marginal forms of pop - are mediated and constrained by the culture industry in one way or the other. That is, all are the product of artists who want their music to be heard and appreciated by listeners, and all artists and listeners have their taste and values shaped by what they learn from their own interactions with culture industry. Thus, heavy metal is mediated by the culture industry in a different way to the classical music, but they are both mediated and constrained to some degree by norms and expectations.

Habermas $(1984,1987)$ offers a way of reconciling the pessimist view of the Frankfurt School with the hope and excitement of the Enlightenment. I have written about this extensively elsewhere (Spracklen 2006, 2009, 2011, 2013a, 2015). Habermas (1984, 1987) believes there are two ways of thinking and acting in the world. One, thinking and acting in a 
communicative manner, is the way that was cultivated in the coffee shops of the Enlightenment. This has led us to modernity, science and secularism. The other way of thinking an acting is instrumental (Weber 1981), that is, reducing all thought and action to efficiency or ends or profit margins. This way of thinking is behind the construction of the modern nation-state, with its bureaucracy and security forces, and also global capitalism. Habermas $(1984,1987)$ believes humans can use communicative rationality to build what he calls the 'life-world', the space where humans can act freely with one another to explore the human condition. But instrumentality today is colonizing the life-world. Music, leisure and culture have the potential to be communicative for Habermas, but that potential is limited by the power of capital and other systems of control.

Bauman (2000) is an important text that attempts to reconcile freedom and constraint in this period of time. Bauman has been criticised for making claims without any evidence, and also for plagiarising his own writing (Best 2016; Davis 2017). This was probably a function of his illness in his later years. Liquid Modernity (Bauman 2000), however, is Bauman at his sharpest, and his most influential. Bauman sets out to build a Marxist critique of the modern world, while building on the ideas of Habermas and Adorno. Bauman (2000) suggests that the postmodern conditions - the loss of structures and certainty, the rise of neo-liberalism, the loss of jobs and the rise of global flows - experienced in the contemporary world are a reflection of modernity itself being liquid. Liquid modernity makes agency uncertain for everyone: nationstates and capitalists as much as individuals on the street. That is, everybody tries to have agency, and everybody tries to take control. This sounds very postmodern, but the condition or game of liquid modernity is still made in a way that provides winners and losers, and is still ragged to favour those with power at the start of the game. Those with money and hegemony will usually retain it - but not always. Sometimes people win by gaining power, or wealth, or status, or just agency and control over their destinies. On the flip side, there are losers ('flawed consumers') marginalized by their failures and choices: nation-states losing their ability to decide legislation that might limit global capitalism; the old working-classes of the global North; the majority of the populations in the global South; or fans of rockabilly or rugby league, leisure activities deemed marginal and unfashionable. Bauman's ideas have been transformed by Blackshaw $(2010,2014)$ into his theoretical framework of liquid leisure. For Blackshaw (2010), any attempt to use what he calls zombie concepts such as power and inequality to understand liquid leisure is doomed to failure, because there is no way of making ethical or political judgements about leisure. While Blackshaw's understanding of Bauman (2000) makes the central concept thoroughly epistemologically and ontologically relative, in this paper I want to use liquid modernity in a more cautious manner, in a way that aligns Bauman to Gramsci, Adorno and Habermas. ${ }^{4}$

\section{Methods}

The data have been collected using the framework and practice of Discourse Tracing (LeGreco and Tracy 2009), collection method and form of analysis I have used in other research on heavy metal and leisure spaces more broadly (Spracklen 2013b, 2014, 2017). The theoretical framework and my knowledge of metal as a scene insider gave me a list of discourses that might appear in the field. Discourse Tracing is not formal content analysis, it is a way of

\footnotetext{
${ }^{4}$ Bauman, liquid modernity and leisure are also found in recent work I have published with Swain and Lashua, based partly on Swain's PhD research (Swain, Spracklen and Lashua 2018). That paper uses khat-chewing among British-Somali youth as an example of a reaction against the anomie of liquid modernity.
} 
exploring ideas and themes across different levels of discourses. There were no keywords used in the search, no dates that set the lower and upper limits of the search. I was simply searching for interviews with the band since the change and comments by fans about the change. In this case, my inside knowledge of the scene allowed me to limit the tracing to official music sites owned by the industry itself - such as record labels, official band sites - as well as unofficial music media sites and fan-sites. I then searched all the known metal web-sites that fell in the above categories, but mainly relied on metal-archives.com because it is the number one site for reviews written by fans. I also searched more generally for interviews with and features about Opeth in the wider music press online. ${ }^{5}$ All this gave me enough data to make sense of the discourses, while providing a small enough set of information to be able to analyse by close reading and annotation by hand.

\section{Åkerfeldt: The New Direction for Opeth}

The main driver of the change was the band's key songwriter, guitarist and singer Mikael Åkerfeldt. He has been in the band for the longest time (although he was not its founder), and he is its de facto leader. And he has been that leader since the band first signed to Candlelight Records. The band have had a number of other members come and go through the years. In public, Åkerfeldt says little about why band members leave - what is clear is that Åkerfeldt has a strong view about that he considers to be the vision and meaning of Opeth, and sometimes that means musicians get replaced by ones more aligned to that vision. However, the new direction - essentially dropping the extreme metal altogether between Watershed and Heritage - arrived with the main players on that last 'metal' album still in place: guitarist Fredrik Åkesson; drummer Martin Axenrot; and bassist Martin Mendez. Admittedly the guitarist and the drummer were relatively new to Opeth, but they were metal musicians who could handle complex parts. This is how Åkerfeldt recalls how the new direction emerged in the writing and recording of the Heritage album, as told to the music web-site Blabbermouth (2016): ${ }^{6}$

It wasn't a decision that we sat down and discussed. The decision happened on its own; it happened in the middle of a creative process actually, because I was writing what was going to be our tenth record ['Heritage']. It was kind of heavy, like a continuation of the stuff we were best known for: very dynamic music and mainly screaming, death metal vocals. But I guess I was fooling myself when I was writing that kind of stuff. I was fooling myself that I liked it and that it was the right thing to do. I played some stuff to Martin Mendez, who plays bass in OPETH, and he said something along the lines of, This is not what we should do.' He didn't say 'This is not good enough,' he just thought it wasn't interesting, and he was right. We kind of milked that sound to the very end. It was liberating. It was fantastic, I have to say. I feel more free. I'm not gonna say anything bad about metal, because I love metal, but we felt shackled in that kind of sound that we had created and I wanted to move on a little bit. And once we dared to make that step, it felt like a rejuvenation and I lost all fears of everything. Now it just feels like I can focus on writing good music and I don't necessarily feel the need that we, as a band, have to fit in anywhere. Even though I love those early records, I want

\footnotetext{
${ }^{5}$ I do not read Swedish, so the research was limited to English-language sites.

${ }^{6}$ From this point all quotes used in the analysis are printed as originally published, with no attempt to present them free of any errors in spelling and grammar. This allows the full emotion of Åkerfeldt, the reporters and the fans to be felt without an academic intermediary (LeGreco and Tracy 2009).
} 
to expand my singing. But I was afraid, a bit nervous people will completely stop liking us and we'll be reduced to nothing and have a job cleaning toilets. I guess I was a little bit afraid for our career, but that was the biggest warning sign; to cater to a career could have been the worst thing I think I could have done. I need that type of honesty when I write music otherwise it's going to end up being shit, I think.

This interview and many others exactly like it suggest a number of reasons for the change in direction. First of all, Åkerfeldt wants to be true to his artistic agency. He wants to follow what he believes to be his true creative path. He did not want to be defined or restricted by something (death-metal growls, aggressive metal riffing) he did not feel inspired to use in the creative act. Ákerfeldt suggests here that being metal would be lucrative but 'false'. That is, it would have been profitable to reproduce what their fans wanted, the same light-and-heavy music, the melodic death metal with prog interludes. This is the kind of music he says he had started to create, locked into the cycle of producing the same albums (with very little change) over and over again. This would be the instrumental rationality (Habermas, 1984, 1987; Weber 1981), which conforms with the constraints of heavy metal and the wider music industry (Adorno 2005). Fans do not want change, and do not want to be challenged much: they want to hear the same music that conforms to the norms of the gene and their expectations. By dropping the metal, Opeth and Åkerfeldt were striking out from the comfort of the album cycle, and the restrictions and fears of metal, and potentially abandoning their chances of making money and making more records. What is also interesting in this reflection is Akerfeldt's suggestion that it was Mendez questioning the new heavy songs that led to Åkerfeldt and Opeth rejecting heavy songs for ones written in the new, prog-rock style. Clearly, Åkerfeldt wants to show that he was not the only band member involved in this turn, and even that he tried initially to write a heavy album.

More crucially for the re-invention and the new direction, Åkerfeldt has talked of his love of seventies prog and rock - and how his habit of collecting vinyl has been a direct influence on the new music. Ever since the release of Heritage, he has allowed journalists to ask him about his record collection. Searching online reveals a string of video interviews with the singer/guitarist explaining the importance of his collection and his musical education. In one article in Louder Sound, for example, he is interviewed with his fellow guitarist Åkesson while dipping into the racks at second-hand vinyl shop. This is how the journalist describes the band and their habits (Blake 2016):

Opeth started out as a grunting death metal band in 1990 before morphing into witchy hard rockers with prog tendencies. And you suspect this transformation was engendered by their lead singer crate-digging in record shops like this... It's an expensive hobby, especially for Åkerfeldt. On the band's last US tour he ended up shipping six big boxes of LPs back to Sweden. Fortunately, his girlfriend takes music as seriously as he does. [The new album] ...was inspired by Åkerfeldt's 6,000-strong record collection. One song, The Wilde Flowers, is named after the 60s Canterbury band that included future members of Soft Machine and Caravan. Another, The Seventh Sojourn, is taken from a Moody Blues album title. And "Chrysalis is named after Jethro Tull's record label," he says. In fact, Tull were such an influence on The Sorceress that two songs had the working titles Jethro 1 and Jethro 2. 
It could not be any clearer. The band have moved on and embraced the new sounds found on the old records Åkerfeldt has acquired. This is a communicative leisure choice made by him as it is his freedom as an artist to follow his muse. Moreover, this is Akerfeldt demonstrating he is not a flawed consumer (Bauman 2000). He is abandoning the structures and ideologies of extreme metal for something that proves his worthiness as someone with taste because liquid modernity enables him to switch and borrow to make new hybrid forms. This, however, misses one point about Opeth: the band always had more to their music than death metal. It could be argued that Åkerfeldt has remained true to the music of Opeth - which has always drawn on prog rock and always used clean vocals - by embracing those non-metal shades completely, and this is an argument he has used himself. ${ }^{7}$

\section{Reactions from Fans}

It is fair to say that the new direction has divided the Opeth fanbase. In my own circle of friends, there is one person who refused to listen to any of the 'new stuff' because Opeth had deliberately distanced themselves from the death-metal style that drove their sound. On the internet, there are blogs and comments under YouTube videos that accuse Akerfeldt of betraying metal, or 'proper Opeth fans'. When Opeth first toured the Heritage album, they made a conscious decision to only play songs that did not have death-metal growls. That meant most of the well-known hits were absent, despite fans heckling for them. I did not attend any of these gigs, but I was aware of the mutterings and the exasperation. One blogger online related their astonishment at being surrounded by these angry die-hard fans: ${ }^{8}$

The Dylan parallels were quite striking on the first leg of the Heritage tour, which featured no songs with the old death growls. At the gig I attended, audience members shouted "play some metal" between songs, and this heckling became more pronounced as the show wore on with no metal in sight. Opeth's style may not be as openly confrontational as Dylan's, as he at times seems to relish pissing people off with a delight almost as evident as Lou Reed's. But Opeth and Akerfeldt certainly aren't overly concerned with placating people, either.

Since that tour, Opeth have played the older angry metal songs alongside the new progrock songs. I went to see the band play in November 2017 in Manchester. The people in the audience were a mixture of metal-heads and older prog-rock fans. The metalheads around us were cynically dismissing the prog-rock turn before the start of the gig, and calling Akerfeldt a 'pretentious wanker'. For those fans, Åkerfeldt has betrayed them, but they still feel like turning up at an Opeth gig to shout at him using their communicative leisure time. Even in the middle of the gig, when the band was playing songs from the new album, fans shouted for old songs. These were only a small handful of hecklers, however: most people at the gig loved it. That is, most fans who have paid their money to see the band do so because they like the new songs as well as the old songs. They are comfortable with this liquid-modern phase of hybridity associated with the band and its new direction. But they are comfortable being part of the

\footnotetext{
${ }^{7}$ http://www.invisibleoranges.com/interview-mikael-akerfeldt-opeth/, published 22 July 2014, accessed 30 June 2018.

${ }^{8}$ http://www.heavyblogisheavy.com/2016/09/23/opeth-not-the-first-musical-act-to-piss-off-their-fans, published 23 September 2016, accessed 30 June 2018.
} 
instrumentality of the music industry, paying excessive costs for tickets and beer just so they can say they have seen Opeth again.

A more interesting way to gauge the opinions of fans is to look at how albums are reviewed, and what people say about those albums, on metal-archives.com. This site is designed to allow metal fans to rate albums and write lengthy reviews. It is well-known and well-used. The fans who write reviews or rate albums are not taken to be a representative sample in any statistical way. But these reviews reflect the opinions of fans who want to write about these bands and albums: fans who want to rave about things they love; fans who want to complain about things they hate; and others who want to engage in serious criticism and who might want to develop an identity as a reviewer.

At metal-archives.com on 28 April 2018, Still Life is rated 85\%, but gets 16 90-100\% scores out of 22 reviews (and is brought down by a rogue 6\%); and Deliverance also gets $85 \%$. These two albums are the fan favourites, and that favouritism reflects the critical response to those two albums. These are the albums that almost everybody likes because they combine the ferocity with the transcendental. At the bottom of the Opeth album popularity parade, Heritage gets $63 \%$ from 21 reviews. Someone called TheDefiniteArticle gave it the lowest rating - a tiny $12 \%$ - in a review titled 'Essentially a bad imitation of 70 s prog': 9

So here is the album on which Akerfeldt has finally dropped his harsh vocals. This may have come as a surprise, but Opeth's progression over the years (from fairly standard death/doom on albums like Orchid and My Arms, Your Hearse to ever more progressive styles on later albums, really starting with Still Life but coming into full swing by its follow-up, Blackwater Park) should have made it clear that this was going to happen. Indeed, not only has he limited himself to clean vocals, but nearly all semblances of metallic riffs are gone. This is, in essence, a progressive rock album and it goes 70s all the way (which is evident from the awful artwork alone) - although this may please fans of retro-rock, it is almost undeniable that instruments like the mellotron haven't been used in rock or metal for a long time because they do not fit with modern production values, and either drift into the background or stick out like a sore thumb... despite their descent in quality (which, over the last few albums, has been rather rapid), one of Opeth's strengths has always been creating instrumental parts which are compositionally intriguing. This is gone. Simply slipped away to whatever far away planet Opeth have left their inspiration at between albums. This wouldn't be a problem - indeed, many bands write interesting music with little or no tonality - but the riffs, while complex, simply have no staying power with the listener. No riff like the opener of 'The Grand Conjuration', no riff like those in 'Demon Of The Fall', simply nothing. This is inexcusable - not just for a metal album (which this quite plainly is not), but for any rock album whatsoever...

TheDefiniteArticle claims to know much about how Opeth created the music in the earlier albums. The absence of the things that made those albums great are the reason why this reviewer has given Heritage a low score. Metalheads need a riff, a big riff, that is catchy, and all the riffs on the album 'have no staying power': they are weak in this reviewer's mind. And he believes mellotrons are too weak when used with modern metal, and work against the power

\footnotetext{
${ }^{9}$ https://www.metal-archives.com/reviews/Opeth/Heritage/307944/TheDefiniteArticle/240707, posted 20 September 2011, accessed 14 April 2018.
} 
of modern metal production techniques (Herbst 2017). The reviewer continues by focusing on the next problem they have with the album, the clean vocals:

I'm sure that the aforementioned lack of harsh vocals will end up being the main talking point about this album, and there's a good reason why. Whilst I have praised Akerfeldt's work in Bloodbath, ${ }^{10}$ and indeed earlier Opeth, that is purely for his harshes. They have a richness to them, amplified by the warm production on those albums, which make them a joy to listen to. By comparison, and indeed by comparison to most vocalists, his cleans fall well short. They're not unlistenable, but purely lacklustre. They sound as though there is no effort being put into them, and thus emotionless. Simply put, this album is Damnation part 2. The least critically acclaimed album in Opeth's back catalogue, essentially replicated, but somehow they've managed to remove all the parts which made even that album the least bit palatable along the way. Sadly, Akerfeldt is resolute in his direction, and I really doubt now, moreso than ever before, that Opeth will ever release another good album.

This is a very damning review. If the new direction is all about favouring the clean vocals that were acclaimed on earlier albums, then this reviewer thinks it is has been a forlorn attempt. The clean vocals on all Opeth's albums are merely 'lacklustre' according to this fan, so an album filled with them makes this fan angry and despondent. However, despite some fans rejecting Heritage, others have embraced it, with one reviewer awarding it $98 \%$ and calling it 'almost perfect' and 'a candidate for album of the year' 11 .

Similarly mixed reviews have followed the release of the two albums after Heritage: Pale Communion (2014) and Sorceress (2016). Both have maintained the progression of the new direction, rejecting any metal while embracing sounds from Åkerfeldt's record collection. As of 28 April 2018, there were nine reviews of Sorceress, providing it with an average rating of $68 \%$. This album really split the fans even more than Heritage, as can be seen in the summary at Table One. ${ }^{12}$

\section{Table One}

\begin{tabular}{|l|l|l|l|}
\hline Review Title & Score & Reviewer & Date \\
\hline $\begin{array}{l}\text { Witchcraft from the } \\
70 \text { 's }\end{array}$ & $93 \%$ & Livingwave17 & 4 March 2018 \\
\hline A very thin soup & $52 \%$ & Slynt & 17 October 2016 \\
\hline $\begin{array}{l}\text { I'm a sinner, and I } \\
\text { worship evil }\end{array}$ & $80 \%$ & Insin & 14 October 2016 \\
\hline $\begin{array}{l}\text { What is this new } \\
\text { devilry? }\end{array}$ & $64 \%$ & PassiveMetalhead & 08 October 2016 \\
\hline Prog Perfection & $90 \%$ & RichardDeBenthall & 07 October 2016 \\
\hline $\begin{array}{l}\text { Opeth have become a } \\
\text { tribute act }\end{array}$ & $3 \%$ & Blackmetalman666 & 06 October 2016 \\
\hline
\end{tabular}

\footnotetext{
${ }^{10}$ Mikael Åkerfeldt formed Bloodbath with other metal musicians to play furious death metal.

11 https://www.metal-archives.com/reviews/Opeth/Heritage/307944/mot_the_barber/90602, posted 15 October 2011, accessed 13 April 2018.

12 Made by the author, based on https://www.metal-archives.com/albums/Opeth/Sorceress/593029, accessed 28 April 2018
} 


\begin{tabular}{|l|l|l|l|}
\hline Opezzzzz.... & $47 \%$ & kluseba & 03 October 2016 \\
\hline $\begin{array}{l}\text { Opeth's best since } \\
\text { Ghost Reveries }\end{array}$ & $90 \%$ & Opeth945 & 02 October 2016 \\
\hline $\begin{array}{l}\text { Make Opeth Metal } \\
\text { Again? }\end{array}$ & $92 \%$ & Metantoine & 01 October 2016 \\
\hline
\end{tabular}

Four of the nine reviews score 90 or higher, one scores a measly $3 \%$, and there is a scatter of three middling scores as well as the very good but not brilliant $80 \%$. The titles of the reviews are interesting because they show us very clearly how the reviewer-fans think. The person who has scored it at $64 \%$ actually likes the progression Opeth have made, but is clearly miserly in the allocation of points - the devilry is the change, and thus reviewer likes it, even though they note that many fans do not. The titles of all four of the ninety-plus reviews show that the reviewer-fans in each instance love progressive turn, and are keen that the band does not actually return to melodic death metal or death/doom metal. The answer to the question posed by the reviewer-fan Metantoine is no thanks, please do not make Opeth metal again. More challenging are the titles of the three lowest scored reviews: they claim in turn that there is nothing of substance to the album and to the band; that the new album will send you to sleep because it is boring; or that the band has become as real and authentic as a prog rock tribute act. The review by Kluseba ('Opezzzzz..... '), who gives the album a mere 47\%, starts: ${ }^{13}$

On its most recent record, Sorceress, Opeth continues its predictable worship of progressive rock of the seventies which began with the weak Heritage (half a decade ago) and continued with the fairly average (by my prog standards) Pale Communion two years ago... Opeth's continued attempts at recreating the magic of their idols sound elitist, pretentious, and tiring to my ears. What this album doesn't do is add anything fresh, inspired, or surprising to the mixture, and the heaviest thing about Sorceress is its album cover. In brief, this really is a frustratingly conservative progressive rock album and nothing more... Opeth itself has changed its sound so drastically that it has now almost completely lost its own initial (and much more unique) identity as one of the world's premier melancholic progressive doom/death metal acts.

This reviewer is clearly a fan of the original Opeth sound, and is angry that the band has abandoned its unique identity that combined the heavy with the quiet, the metal with the progression. They are disappointed with the music offered by the band since the change in direction, and they want others to know that it the problem they have with the new Opeth is there is nothing new or progressive about it. This fan is the classic flawed consumer of liquid modernity, but they are using their communicative rationality to argue their point in this leisure space. Kluseba finishes by saying:

Those who are expecting a truly progressive sound, elements from different metal subgenres, or fresh and liberating ideas should ignore this album and distrust the numerous surprisingly positive reviews by dependent metal magazines.

\footnotetext{
${ }^{13}$ https://www.metal-archives.com/reviews/Opeth/Sorceress/593029/kluseba/238242, posted 03 October 2016, accessed 28 April 2018.
} 
Kluseba thinks there is some kind of 'payola' at work (Cooper 1990): what else can explain the positive reviews of an album Kluseba does not rate in the 'dependent' metal magazines? This is the truth of the music industry, associated as it is with the broader instrumental rationality of the culture industry and global capitalism (Adorno 2005; Adorno and Horkheimer 2016; Habermas 1984, 1987; Spracklen 2014, 2015). We know bands and labels paid for their music to be hyped in the past (Cooper 1990; Fairchild 2012), and Kluseba wonders whether the metal media is favouring Opeth in return for some favour or other. The notion that Opeth are not being original is at the heart of the review by Blackmetalman666, who scores the album at the lowest score so far. We can assume he is a man, given his user name. What is funny about his user name is that he wants to identify with black metal, the most extreme, reactionary and conservative underground sub-genre there is in the wider genre. With a name like that, we should not be surprised he does not like the new direction. However, as he says: ${ }^{14}$

My problem is not that there is a lack of growls or death metal influences, but that this simply does not sound like Opeth. Mikael Åkerfeldt sounds like tired, and extremely nerdy compared to how he sang on say, 2002's Deliverance. He attempts to sound dramatic, but comes across more like he's trying too hard to imitate other prog singers... The first time I heard Opeth's Still Life, I truly never expected that the same genius songwriter would go on to spew out something so banal \& difficult to listen to. To reiterate, it's clear that Opeth are becoming a tribute act to 70's \& 80's prog, which is truly an insult to the fans who have been with Opeth since near the beginning, and who expect a certain quality of musicianship from the band. Nobody dislikes Opeth's recent catalogue because it isn't death metal, people don't like it because it's boring, it's pretentious, it shows Opeth becoming more posers than actual artists with original ideas.

Being called a poser is the worst thing to be called in extreme metal (Hoad 2014; James and Walsh 2015; Kahn-Harris 2006; Phillipov 2012; Spracklen 2006, 2014). Being a poser is associated with instrumental rationality (Habermas 1984, 1987) - buying into music because it is fashionable or being hyped. Being a poser is also something associated with the liquid modern, the hipster or flâneur who picks and chooses across the whole of culture but is unable or unwilling to commit to anything (Bauman 2000). The Norwegian black-metal scene in the early nineties rejected death metal for being false and full of posers, full of people who were not truly evil, or metal, or Satanic (Spracklen 2006). But the review is not just name-calling and finger-pointing: Blackmetalman666 wants us to know that he thinks Opeth are banal and have lost their creativity. He thinks the album is an insult to the fans who have been with Opeth since the nineties - the true fans who expect the band to deliver on quality musicianship. He says he is not angry because the band have dropped the death metal growls, but he seems to protest too much on that point, because he also tells us Åkerfeldt sings better on Deliverance, one of the heaviest albums of the back catalogue.

If anger and boredom are the emotions evoked by the reviewer-fans who reject the new direction, elation and joy are the emotions that are evoked by the four reviewer-fans who have given the album the highest cores. Three of them make sure that the reader knows they are

\footnotetext{
${ }^{14}$ https://www.metal-archives.com/reviews/Opeth/Sorceress/593029/Blackmetalman666/351998, posted 06 October, accessed 28 April 2018.
} 
long-standing fans of the band who have followed Opeth intro the new sound. The final reviewer who loves the album is Livingwave17, the person who scored it at the very high $93 \%$. This is how they introduce their review 'Witchcraft from the 70's': ${ }^{15}$

Nobody can say that they are a true admirer of the progressive death metal genre unless they have heard Opeth. I have heard lots of talk about this legendary band and while I love prog-death metal myself, I had to finish my homework and fill up this big gap in my musical collection. After hearing Sorceress I am left quite surprised and pleasantly impressed with what this band can put out but I understand that this is not exactly what they are known for. As it seems that many bands tend to do lately, I hear that Opeth has also suffered some changes leaving behind many of their trademarks but nevertheless their last album is very enjoyable...

This person is happy to admit they have not been a devoted fan who has followed Opeth ever since the first demo tapes. They have a range of musical tastes and are a big fan of progdeath metal (Marrington 2017). They have heard about Opeth and have started to get into the band by listening to their albums as 'homework', presumably over a short period of time. They are aware that Opeth have changed their sound and there are mutterings about this by people who love the old sound. They go on to say:

While I know that this isn't typical Opeth material I have heard a lot about them and I know that you should expect quite an aggressive sound with with even some harsh voices. On "Sorceress" though, there are no harsh vocals .Soft clean singing that sometimes even goes in falsetto is the only vocal you will hear. Don't be disappointed though because the voice is very good and expressive. If Opeth's typical sound is what you live for then this release will be a let down, but we cannot deny that it is a very masterful album. On top of the lack of harsh vocals in favor of a softer sound, we see a huge amount of clean instruments as well as slow paced sad songs... After reading a bit about Opeth and this album, I can see how this sound would appear. The main creative mind of the band is Mikael Åkerfeldt and he just so happens to be a collector of 70's vinyls. He actually says that the song "Dun Ringill" by Jethro Tull has influenced his writing on this record. So if you want to see what happens when a proper progressive death metal band is fronted by a 70's enthusiast with a moustache, this is THE place to be. This creative influence has given Opeth it's oldie but goldie vibe. On top of that comes the soft sad stuff that I mentioned earlier. So this is a two faced musical creation with dark depression on one side and classic nostalgia on the other. Really do check it out because it's a unique combination.

For this fan, Opeth are still a band that combines heavy and light moods. The singing is perfect. The progression towards prog is something that makes the album the best attempt Opeth have made to capture complexity, melancholy and beauty. The mention of the wellknown British seventies band Jethro Tull marks this reviewer as being someone who has come from the prog-rock scene, or someone who wants the reader to think they come from that scene.

\footnotetext{
15 https://www.metal-archives.com/reviews/Opeth/Sorceress/593029/Livingwave17/413797, posted 04 March 2018, accessed 28 April 2018.
} 


\section{Discussion}

Fan studies theorists argue that being an active fan means shaping one's identity and exercising one's power in a transmedia culture, underpinned by a postmodern world (Bennett 2014; Ford 2014; Gray, Sandvoss and Harrington 2017). That is, fans are not passive consumes of popular culture, as Adorno would have it, nor are they merely recipients of mass culture fed to them by Gramsci's hegemonic sleight-of-hand (Altheide 1994; Gramsci 1971). Using the ontological and epistemological framework of Habermas (1984, 1987), we might say that fans in this new post-industrial world of ours use their fandom as a resource of communicative action, a form of cultural capital (Bourdieu 2013), to construct the life-world against the rise of capitalism and instrumentality. Fans express identity, belonging and community through the playfulness of their appropriation of the popular culture sold to them, and use their fandom to construct what I have called communicative leisure (Spracklen 2009, 2011): meaning and purpose for themselves now we can no longer find meaning and purpose in families, work and the structures of modernity. Habermas $(1984,1987)$ calls the post-industrial period that we live in late modernity: here there are a few spaces left for communicative agency but all is threatened by instrumentality. Bauman (2000) calls the period in which we live in liquid modernity. It seems to me that late modernity and liquid modernity are essentially the same place, though Bauman and his followers would argue that even the hegemons have the potential to lose power tomorrow (Blackshaw 2010), whereas Habermas $(1984,1987)$ is more cynical about the ability of the elites to maintain their power. To modify Bauman's metaphor, liquid modernity flows all around us but the elites still have the resources to freeze it in a way that favours their interests.

The condition of liquid modernity combined with the fact of Habermasian instrumentality means people of this new century are short of meaning (Spracklen 2009). Fandom acts as a space where people can attempt to find meaning, subject to the limitations of liquid modernity, and the instrumental logic of capitalism and commodification. Metal - and extreme metal - is viewed by insiders as being a site of agency and resistance; although outsiders see it as marginal or residual (Kahn-Harris 2006; Phillipov 2012; Spracklen 2006, 2014). That is, extreme metal fans want their music to sound like extreme metal. They want the music they like to be imbued with the mythologies and ideologies of extreme metal (Hoad 2014; Kahn-Harris; Phillipov 2012; Spracklen 2014): metal is mythologised as being against the mainstream, against religion and authority, against pop music, for the underground, for the individual, for hegemonic masculinity (Connell 2005). Extreme metals bands such as Opeth inspire enormous amounts of seemingly irrational devotion. Getting into Opeth as an extreme metal fan in the nineties and twenty-hundreds meant declaring one's love of the band through buying t-shirts, hoodies, and inscribing the Opeth logo for ever on one's body in the form of one or more Opeth-related tattoos. ${ }^{16}$ All this was bought and paid for despite the fact that such clothing and body ornamentation made it less easy for the Opeth fans to fit in in everyday, mainstream society. Listening to Opeth marked one out as a fan that could listen to long, complicated metal that ranged from the heaviest of riffs and the deepest of death-growls to the lightest, transcendental moments. Being an Opeth fan made one look down at the people who listened to mainstream metal bands, or rock bands. Opeth have tried to retain that cleverness about their music, but Mikael Åkerfeldt has abandoned the aggressive metal parts that originally attracted many of the fans in the first place. For some fans, this is a step too far for

\footnotetext{
${ }^{16}$ Of course this not unique to Opeth. All metal acts inspire the same devotion and practices (Hill 2016; KhanHarris 2006; Phillipov 2012; Walser 1993).
} 
them, and they cannot follow the band any more. They stop wearing the t-shirts, cover up or re-shape their tattoos. For others, the new direction is still Opeth, still part of the progressive nature that the band exhibits in its early albums. For these fans, they can still buy the albums and t-shirts and be sure in their taste, their fandom, and their identity. And the success of the band's recent concerts suggests that the band has found more than enough new fans to replace the ones who want the metal back. Most of the current Opeth fans are happy with the choices they are making in liquid modernity - they are paying money and finding meaning still.

Ironically, despite Mikael Åkerfeldt's belief in his ability to follow his creative muse anywhere it takes him, there are limits. Opeth's creative choices are constrained by the popular music industry, and the norms of extreme metal (being true, being individuals, not selling out). If Åkerfeldt needed to follow his muse he should have left the industry or re-invented himself as a jazz singer or something equally audacious - instead he has remained in it. He and the band are still signed to Roadrunner Records, they still tour and release albums like any other professional rock act. They play the game of doing interviews and promoting their product like true professionals. Fans in turn are constrained by the belonging and meaning they display in their purchases, but they do have the agency to stop buying Opeth products. If Opeth decided to transform themselves completely into a barbershop quartet, because that was how Mikael Åkerfeldt felt his muse was heading, they would soon lose their contracts, and most of their fans, and their lives and identities as professional rock musicians.

\section{Conclusion}

This paper has only captured a snapshot of ideas and feelings from the band and their fans. More systematic research clearly needs to be done to understand how heavy metal bands and fans change in this new liquid modern period when popular music is global and maturing. But some tentative conclusions can be made about Opeth and some of their fans. For the band, their search for an authentic musical identity based on vinyl nostalgia is an expression of contempt for the instrumental rationality and in-authenticity of modern metal. They believe the period encompassed the cultural capital of progressive rock was a true public sphere, a lifeworld even (Habermas 1984, 1987), in which musicians could use communicative rationality to make meaningful musical statements: art not product; creativity not commodification. This is hipsterish, fake authenticity and nostalgia (Zukin 2010). In fact, the popular music industry was as instrumental and commodified in the vinyl age as it is today. Rock music was sold through albums as a way of invoking Bourdieu's (2013) notion of taste and distinction, as well as Veblen's (2005) conspicuous consumption. Labels and managers spent millions of dollars creating the artwork of the covers as part of promotional campaigns. The vinyl that has survived is curated and fetishized as something more real than a download, yet it was constructed for the same instrumental reason. However, it cannot be denied that this music was more creative and experimental than most of mainstream pop (and mainstream rock and mainstream metal). So the impulse of the band and the fans who have followed them into this new direction is understandable.

For the fans who have rejected the new direction, their anger is the anger of Bauman's flawed consumers in leisure spaces. Opeth have changed too much for these fans. That change is not something these fans need or desire. These fans are angry that the band and the style associated with the band - and their fandom - has been changed. For some of these angry fans, the new direction is something they reject simply because they want to hear angry metal. For these, perhaps, the angry metal offered a release from the liquid modernity of Bauman (2000), 
and a way if hiding the fact these fans have not being successful in this new age. But others reject it because Opeth have stopped being part of the community of extreme metal, the space in which these fans find identity and meaning.

\section{References}

Adorno, T. W. (2005). The culture industry: Selected essays on mass culture. Abingdon: Routledge.

Adorno, T., \& Horkheimer, M. (2016). Dialectic of Enlightenment. London: Verso.

Altheide, D. L. (1984). Media hegemony: A failure of perspective. Public Opinion Quarterly, 48(2), 476-490.

Bauman, Z. (2000). Liquid modernity. Cambridge: Polity.

Bennett, L. (2014). Tracing textual poachers: Reflections on the development of fan studies and digital fandom. The Journal of Fandom Studies, 2(1), 5-20.

Berlin, E. A. (2016). King of ragtime: Scott Joplin and his era. Oxford: Oxford University Press.

Best, S. (2016). Zygmunt Bauman: Why good people do bad things. Abingdon: Routledge.

Blabbermouth. (2016). OPETH frontman: Dropping 'screaming death metal vocals' was 'liberating'. Blabbermouth, 23 September 2016. Published online at http://www.blabbermouth.net/news/opeth-frontman-dropping-screaming-death-metal-vocalswas-liberating/.

Blackshaw, T. (2010). Leisure. Abingdon: Routledge.

Blackshaw, T. (2014). The crisis in sociological leisure studies and what to do about it. Annals of Leisure Research, 17(2), 127-144.

Blake, M. (2016). We let Opeth loose in a record store and here's what happened. Louder Sound, 01 September 2016. Published online at: https://www.loudersound.com/features/welet-opeth-loose-in-a-record-store-and-here-s-what-happened.

Bourdieu, P. (2013). Distinction: A social critique of the judgement of taste. Abingdon: Routledge.

Brown, J. A. (2018). \#wheresRey: Feminism, protest, and merchandising sexism in Star Wars: The Force Awakens. Feminist Media Studies, 18(3), 335-348.

Connell, R. W. (2005). Masculinities. Cambridge: Polity.

Cooper, B. L. (1990). From anonymous announcer to radio personality, from pied piper to payola: The American disc jockey, 1950-1970. Popular Music and Society, 14(4), 89-95.

Cossu, A. (2015). It ain't me babe: Bob Dylan and the performance of authenticity. New York: Routledge.

Davis, M. (2017). Freedom and consumerism: A critique of Zygmunt Bauman's sociology. Abingdon: Routledge.

Engesser, S., Ernst, N., Esser, F. \& Büchel, F. (2017). Populism and social media: How politicians spread a fragmented ideology. Information, Communication and Society, 20(8), 1109-1126.

Fairchild, C. (2012). Alan Freed still casts a long shadow: The persistence of payola and the ambiguous value of music. Media, Culture and Society, 34(3), 328-342.

Ford, S. (2014). Fan studies: Grappling with an 'undisciplined' discipline. The Journal of Fandom Studies, 2(1), 53-71.

Frith, S. (1998). Performing rites: On the value of popular music. Cambridge: Harvard University Press. 
Gray, J., Sandvoss, C., \& Harrington, C. L. (Eds.). (2017). Fandom: Identities and communities in a mediated world. New York: NYU Press.

Gramsci, A. (1971). Selections from prison notebooks. London: Lawrence and Wishart.

Habermas, J. (1984). The theory of communicative action, volume one: Reason and the rationalization of society. Cambridge: Polity.

Habermas, J. (1987). The theory of communicative action, volume two: the critique of functionalist reason. Cambridge: Polity.

Herbst, J. P. (2017). Historical development, sound aesthetics and production techniques of the distorted electric guitar in metal music. Metal Music Studies, 3(1), 23-46.

Hesmondhalgh, D. (1998). The British dance music industry: A case study of independent cultural production. British Journal of Sociology, 49(2), 234-251.

Hesmondhalgh, D. (2013). Why music matters. London: John Wiley \& Sons.

Hewer, P., Gannon, M., \& Cordina, R. (2017). Discordant fandom and global football brands: 'Let the people sing'. Journal of Consumer Culture, 17(3), 600-619.

Hill, R. L. (2016). Gender, metal and the media: Women fans and the gendered experience of music. London: Palgrave.

Hoad, C. (2014). 'Ons is saam': Afrikaans metal and rebuilding whiteness in the Rainbow Nation. International Journal of Community Music, 7(2), 189-204.

James, K., \& Walsh, R. (2015). Bandung rocks, cibinong shakes: Economics and applied ethics within the Indonesian death-metal community. Musicology Australia, 37(1), 28-46.

Kahn-Harris, K. (2006). Extreme metal: Music and culture on the edge. Oxford: Berg.

Klein, B., Meier, L. M., \& Powers, D. (2017). Selling out: Musicians, autonomy, and compromise in the digital age. Popular Music and Society, 40(2), 222-238.

Lamont, M. (1992). Money, morals, and manners: The culture of the French and American upper middle class. Chicago: University of Chicago Press.

Lamont, M. (2000). The dignity of working men: Morality and the boundaries of race, class, and immigration. Cambridge: Harvard University Press.

LeGreco, M., \& Tracy, S. (2009). Discourse tracing as qualitative practice. Qualitative Inquiry, 15(9), 1516-1543.

Marrington, M. (2017). From DJ to djent-step: Technology and the re-coding of metal music since the 1980s. Metal Music Studies, 3(2), 251-268.

Marx, K., \& Engels, F. (2002). The communist manifesto. Harmondsworth: Penguin.

Nelson, E. H. (2018). From selling out to savvy strategy: how The OC helped change the stigma around licensing indie music. Creative Industries Journal, 11(1), 54-69.

Opeth. (1999). Still Life. Cleckheaton: Peaceville Records.

Opeth. (2001). Blackwater Park. London: Music for Nations.

Opeth. (2002). Deliverance. London: Music for Nations.

Opeth. (2003). Damnation. London: Music for Nations.

Opeth. (2005). Ghost Reveries. New York: Roadrunner Records.

Opeth. (2008). Watershed. New York: Roadrunner Records.

Opeth. (2011). Heritage. New York: Roadrunner Records.

Opeth. (2014). Pale Communion. New York: Roadrunner Records.

Opeth. (2016). Sorceress. New York: Roadrunner Records.

Paddison, M. (1982). The critique criticised: Adorno and popular music. Popular Music, 2 , 201-218. 
Phillipov, M. (2012). Death metal and music criticism: Analysis at the limits. Lanham: Lexington Books.

Salvaggio, M. (2018). The justification of reconstructive and reproductive memory beliefs. Philosophical Studies, 175(3), 649-663.

Spirou, P. (2014). Walk hard: Film parody, biopics and music. Comedy Studies, 5(1), 52-63. Spracklen, K. (2006). Leisure, consumption and a blaze in the northern sky: Developing an understanding of leisure at the end of modernity through the Habermasian framework of communicative and instrumental rationality. World Leisure Journal, 48(3), 33-44.

Spracklen, K. (2009). The meaning and purpose of leisure: Habermas and leisure at the end of modernity. Basingstoke: Palgrave Macmillan.

Spracklen, K. (2011). Constructing leisure: Historical and philosophical debates. Basingstoke: Palgrave Macmillan.

Spracklen, K. (2013a). Whiteness and leisure. Basingstoke: Palgrave Macmillan.

Spracklen, K. (2013b). Respectable drinkers, sensible drinking, serious leisure: Single-malt whisky enthusiasts and the moral panic of irresponsible others. Contemporary Social Science, 8(1), 46-57.

Spracklen, K. (2014). There is (almost) no alternative: The slow 'heat death' of music subcultures and the instrumentalization of contemporary leisure. Annals of Leisure Research, 17(3), 252-266.

Spracklen, K. (2015). Digital leisure, the internet and popular culture: Communities and identities in a digital age. London: Palgrave.

Spracklen, K. (2017). Bravehearts and bonny mountainsides: Nation and history in Scottish folk/black metal. Rock Music Studies, 4(2), 102-116.

Spracklen, K., Lucas, C., \& Deeks, M. (2014). The construction of heavy metal identity through heritage narratives: A case study of extreme metal bands in the north of England. Popular Music and Society, 37(1), 48-64.

Swain, S., Spracklen, K., \& Lashua, B. (2018). Khat-chewing in liminal leisure spaces: BritishSomali youth on the margins. Leisure Studies, 37(4), 440-451.

Veblen, T. (2005). Conspicuous consumption. Harmondsworth: Penguin.

Walser, R. (1993). Running with the devil: Power, gender, and madness in heavy metal music. Middletown: Wesleyan University Press.

Weber, M. (1981). Some categories of interpretive sociology. The Sociological Quarterly, 22(2), 151-180.

Yavuz, M. S. (2017). 'Delightfully depressing': Death/doom metal music world and the emotional responses of the fan. Metal Music Studies, 3(2), 201-218.

Zukin, S. (2010) Naked city: The death and life of authentic urban spaces. Oxford: Oxford University Press. 